\title{
Intellectual Incest on the Charles: Why Economists are a little bit off
}

\author{
David Colander \\ Middlebury College, Middlebury, Vermont 05753, USA.
}

Eastern Economic Journal (2015) 41, 155-159. doi:10.1057/eej.2014.78; published online 19 January 2015

The economists who make up the mainstream economics profession are super bright, highly intelligent, technically sophisticated, conscientious individuals. But to many outside observers they are just a little bit off — it's hard to capture precisely what is off, but something is. What's off changes. Twenty years ago it was an overemphasis on theory - leaving an AEA Commission to worry that the profession was creating "idiot savants." Today, that isn't the problem. The earlier problem of doing theory for theory's sake has been resolved as young mainstream economists have turned more to empirical work, applying economic models to real world issues. That's all for the good. With the introduction of behavioral economics, modern economics has integrated a much better sense of how real world people act into its models. But still, when one looks at the mainstream profession as a whole it is hard to avoid the sense that there's still something just a bit off. What's now off is the profession's tendency toward fads, and its episodes of lack of judgment, especially when it comes to relating their formal models to policy issues. Somehow too many young economists seem to lack the maturity that Thiel said was required "to realize that models are to be used but not to be believed."

One of the reasons why economists seem a bit off is, of course, simply incentives. Economist's incentives are to write academic papers, not to solve real world problems. Moreover, they have an incentive to overemphasize the importance and implications of their models. But in my view, incentives don't quite explain economist's oddness. A wellbalanced economist would recognize that many of their academic papers have little direct relevance to reality, and would at least admit it in private over drinks, if not in print. I haven't found that to be the case. While it's true of some modern economists, there seems to be fewer of these well-balanced economists in private than there were earlier. What I'm saying is that modern mainstream economists seem to lack the all-round wisdom reflective of the great policy integrators of the past, such as Bob Solow, Charlie Kindleberger, Charles Goodhart, Paul Samuelson, Art Okun, Jim Tobin, Herb Stein, and Paul Streeten, to name just a few.

Let me give a couple of examples of where modern mainstream economics seems a bit off. The poster child case is modern DSGE macro, which has gone off the deep end in drawing policy implications out of models with assumptions that are so far from what fit the economy, or in its New Keynesian version, only adding realistic assumptions after the model has been distorted by a highly limiting tractable DSGE lens. Modern macro has 
gone so much off the deep end that any reasonable outside observer who understands the models and their assumptions, can only wonder what they've been smoking. That's not only my assessment. It is also Bob Solow's, who is considered the father of modern macro by the DSGE modelers. He's DSGE's daddy, and he has disowned his offspring, describing it as a "rhetorical swindle on the lay public." According to Solow, the DSGE models lack credibility and usefulness. I totally agree [Colander, 2013].

A second example of how modern economics is a bit off is in its reaction to Piketty's book, Capital in the 21st Century. Numerous mainstream economists went gaga over it in an almost incomprehensible way, making the book into a publishing phenomenon. As I discussed in Colander [2015], Piketty's book is not a bad book but it is not a book to go gaga over; it is no new classic as it has been portrayed by many in the mainstream. It is a book with serious theoretical flaws, unsupported policy discussions, and a number of $a d$ hoc criticisms of the profession, which if made by a heterodox economist, would have led a mainstream economist to put down the book and say it is not worth reading. Yet, mainstream economic reviewers passed over all those problems, and declared it a masterpiece. That's inexplicable to me.

\section{INCEST AND ECONOMICS}

I could go on, but my goal in this paper is not to argue that modern mainstream economics is just a little bit off, but rather to tentatively accept that it is, and offer a reason why. That reason is intellectual incest. Modern mainstream economics is a bit off as a result of too much inbreeding. Specifically, my argument is that the gene pool of economists in the replicator dynamics of the profession is too small to prevent undesirable recessive traits from showing up in mainstream economists from time to time.

Let me start by considering how big the economic intellectual gene pool is. Each year about 25 newly minted Ph.D. economists have a shot at making the top echelons of the economics profession. There are probably another 50 or so graduates who have a small shot at making it. So the intellectual genealogy of these 75 economists a year is central to understanding the profession, and its foibles. That elite group determines the future direction of the profession, just as the monarchies of old did. These elite are the super peers; they set the agenda, and provide the role models for the others.

The problem is, like monarchies of old, there's a lot of inbreeding that has reduced the intellectual gene pool of this group to a size that cannot avoid serious inbreeding. A diverse intellectual gene pool would have those graduates coming from different traditions so that undesirable recessive traits of any one tradition are less likely to be expressed in the offspring. So the reason economists are a bit off, and go off on DSGE fads, and too often seem to not reflect an educated common sense, is that the intellectual reproduction of this group does not have enough diversity.

Intellectual inbreeding allows recessive traits and tendencies, which in the original breeding stock were not all that harmful, to become dominant. That's what happened with DSGE macro. It reflects a recessive trait in its daddy, Robert Solow. DSGE macroeconomics (which includes just about all mainstream modern macro) is a mutant Solow strain, attributable to one of his recessive traits. That trait was a strong, dare I say excessive, aversion to informal models, which resulted in an almost visceral reaction to informal presentations of models, and a similarly strong preference for small semi-rigorous models that fit the real world. When those traits are bred with an Arrow-Debreu, Samuelson trait expressing a strong preference for highly rigorous formal general equilibrium models, the result is modern DSGE macro. 
With their other almost off-the-chart abilities, and with their almost unbounded educated common sense, Solow and Samuelson could compensate for their recessive traits, thereby coming up with useful models and policy insights. (Debreu, similarly, could recognize the limitations of his model and know enough to not relate his work directly to real world problems.) Their judgment allowed them to limit the applicability of the models. For example, Solow, writing about how he used his growth model and why he objects to how modern economists are using it, stated: "I restricted the applicability of the model to tranquil trajectories without stormy intervals ... [and] I immediately warned the reader of the possibility of aggregative short to medium run imbalances that would not fit in to the model." Modern macro followed Solow on the focus on formal modeling, but not on the judgment about use of models. The result was modern macro. So whereas Solow's judgment gene compensated for his recessive anti-informal modeling gene, and made him into an eminently reasonable economist, it did not in his intellectual offspring. Solow is the daddy of modern macro, and he has the good judgment to disown it.

The Piketty problem shows a different result of the intellectual incest. It reflects top economist's differential treatment of their offshoots. If one of their own (Piketty is trained in an MIT tradition, and taught at MIT for 2 years) raises a policy issue they believe should be raised, they pull their punches when assessing it, and convey a sense that the contribution is larger than it is. For example, had a heterodox economist, or other outsider, written that "economics has yet to get over its childish passion for mathematics," as Piketty did, the elite would have stopped reading and paned the book. With Piketty, they overlooked it and numerous similar gratuitous statements.

\section{INCEST ON THE CHARLES}

To get a handle on how much inbreeding is taking place in the top echelons of the profession, I collected data on some measures of inbreeding within the upper echelons of the economics profession. Specifically, I collected data on where economists at some top economics programs received their training and how different top programs compare in their diversity. ${ }^{1}$

My hypothesis was that a diverse gene pool would have significant cross-breeding in which programs hire from other departments where students had training in a different tradition. If cross-breeding does not take place, problems can develop.

Table 1 provides what I call a dispersion index, which gives a measure of the intellectual diversity in some top programs. To derive it I calculated the ratio of the number of different programs from which professors come to the total number of professors in the department. The higher the dispersion index number the wider the gene pool of graduates of that program. Thus, if there were 10 professors at a program, and they came from 10 different programs, the dispersion index would be 1 . If, however, they all came from the same school, the dispersion index would be 0.1 .

Table 1 Dispersion index of economics program faculty

\begin{tabular}{lr}
\hline MIT & 0.23 \\
Harvard & 0.27 \\
Stanford & 0.31 \\
Princeton & 0.37 \\
Yale & 0.44 \\
Chicago & 0.50 \\
\hline
\end{tabular}


As you can see from the table, MIT and Harvard have the lowest dispersion index, which means that they have the smallest gene pool of the programs listed. Chicago has the largest, which is still only 0.5. This low number for MIT and Harvard tells us that professors at these top programs come from a relatively small group of programs, and that the most inbreeding occurs at MIT and Harvard and the least at Chicago. To get some sense of whether this seemed unusual, I calculated the dispersion index at Harvard and MIT for their English departments. These were much higher: 0.46 for Harvard and 0.73 for MIT. So the gene pool in economics at Harvard and MIT is much smaller than the gene pool in English at Harvard and MIT.

As a second measure of gene pool diversity in Table 2, I calculated the number of faculty coming from that faculty's own program. Again Harvard and MIT came out with the least diversity. Twenty-six percent of Harvard's professorate came from Harvard, and 23 percent of MIT's professorate came from MIT. So as was the case with the dispersion index, Harvard and MIT demonstrate the most inbreeding by this measure, with Yale demonstrating the least.

The above two tables tend to underestimate the amount of inbreeding at Harvard and MIT because of their geographical proximity. The two programs are geographically next to each other, and many of their students and professors are connected by the NBER, which is geographically located between the two programs. Because of their geographic proximity, it is reasonable to conclude that Harvard and MIT economic faculty and students interact more than do students at say Princeton and Stanford. To capture this interconnection I looked at the two programs as a connected group, and calculated the percentage of professors who come from either one or the other school. The data are presented in Table 3.

This table is in my view a significant indicator of a high degree of inbreeding on the Charles. As you can see, 61 percent of Harvard's faculty come from either MIT or Harvard, and 55 percent of MIT's faculty come from either Harvard or MIT. Much smaller percentages come from MIT and Harvard at other programs.

There are, of course, many ways to explain or attempt to justify these numbers. For example, one might argue, correctly, that Harvard and MIT are great programs, they get great students, so it isn't surprising that they hire from their own program. But that would be a satisfying explanation only if the high percentages of faculty coming from Harvard and MIT were the case for all programs. As you can see in the table, other programs do not have similarly high percentages of MIT and Harvard backgrounds.

A second justification of the high inbreeding is that a number of professors at Harvard and MIT were not hired directly out of graduate school, but had appointments at other programs between graduation and their current position. So some cross fertilization can occur. This also is of course true. But this justification is, in my view, swamped by the argument that these data significantly underestimate the amount of inbreeding that takes place in the top echelons. The argument is that these data don't take into account the significant inbreeding existing among all these top programs. Because in the past they have hired so many of each other's graduates they can be seen as at best first cousins, and more

Table 2 Percentage of faculty who came from that program

\begin{tabular}{lr}
\hline Harvard & 0.26 \\
MIT & 0.23 \\
Stanford & 0.22 \\
Chicago & 0.18 \\
Princeton & 0.17 \\
Yale & 0.09 \\
\hline
\end{tabular}


Table 3 Professors coming from either Harvard or MIT

\begin{tabular}{lr}
\hline Harvard & $61 \%$ \\
MIT & $55 \%$ \\
Stanford & $38 \%$ \\
Princeton & $34 \%$ \\
Yale & $30 \%$ \\
Chicago & $15 \%$ \\
\hline
\end{tabular}

likely clones. If I had explored how many backgrounds of professors at top 10 programs included exposure to significantly different traditions - say a New School, U. Mass Amherst, or George Mason tradition, there would be almost none, which means that the amount of inbreeding among Harvard, MIT, and their clones would have been almost 100 percent.

\section{CONCLUSION}

My goal in this paper was to explain why mainstream economists seem a little bit off at times. The data provide a likely reason. The mainstream profession seems to be following the path of the Spanish Habsburgs and not controlling inbreeding of close intellectual relatives.

Charlie Kindleberger used to say that MIT didn't eat their young, by which he meant that they didn't hire their own graduates directly upon graduation. Back in the 1960s that limitation on inbreeding may have been enough, since back then other top programs, where the future elite went to mature, had different traditions than MIT did. Today, 50 years later, that restriction is no longer enough. The other top programs are now populated by Harvard and MIT's brothers, sisters, and cousins, so 6 years away from the Charles can almost be like not having left. For the Habsburgs, this inbreeding path ultimately ended with the dynasty of Charles II, a king so riddled with problems that he had trouble chewing food. Modern economics hasn't gone that far yet, but given that amount of intellectual inbreeding that occurs in the top echelons of the profession, and especially on the Charles, it is not at all strange that a few recessive traits pop up now and again, and that modern mainstream economists are sometimes a bit off. What is strange is that they are as sensible as they are.

\section{Note}

1. The data were collected by my research assistant, Wenhao Yu. He went to economic websites of graduate economics programs and determined where listed full time faculty of the graduate economics program (not affiliated programs) received their degree. It was done in the summer of 2014.

\section{References}

Colander, David. 2013. The Systemic Failure of Economic Methodologists. Journal of Economic Methodology, 20(1): 56-68.

. 2015 Marketing Economic Ideas: The Problem with Capital. Eastern Economic Journal, 41(1): 1-5. 